\title{
Changes in progesterone concentrations in the Japanese long-fingered bat, Miniopterus schreibersii fuliginosus*
}

\author{
K. Kimura, A. Takeda and T. A. Uchida $\uparrow$ \\ Department of Applied Biology, Faculty of Textile Science and Technology, Shinshu University, \\ Ueda 386, Japan, and $†$ Zoological Laboratory, Faculty of Agriculture, Kyusyu University 46-06, \\ Fukuoka 812, Japan
}

\begin{abstract}
Summary. In the Japanese long-fingered bat, when compared with the baseline values during non-pregnancy in the autumn, plasma progesterone concentrations were not significantly elevated during the delayed implantation stage that begins before the bats enter hibernation. However, progesterone concentrations were significantly lower during the delayed development stage that occurs during hibernation and rose significantly during the rapid embryogenesis that occurs after arousal from hibernation in the spring. Changes in the corpus luteum volume corresponded closely with those of plasma progesterone values. Maintenance of gravid females at $25^{\circ} \mathrm{C}$ for 2 weeks in winter resulted in significant increases in the plasma progesterone concentration and the corpus luteum volume.
\end{abstract}

\section{Introduction}

Miniopterine bats (Miniopterus species), widely inhabiting the Old World, have a unique reproductive pattern (Uchida, 1957; Wimsatt, 1969; Richardson, 1977; van der Merwe, 1980). In the Japanese long-fingered bat, Miniopterus schreibersii fuliginosus, copulation in mid-October is followed closely by ovulation and fertilization (Mōri \& Uchida, 1980, 1981a, b, 1982). In November, the females enter into hibernation in a pregnant condition and after having experienced a delayed implantation of about 60 days (mid-October to mid-December), the blastocyst begins to implant from mid-December to early January and then undergoes a subsequent period of delayed development (early January to March) (Kimura \& Uchida, 1983). Embryonic development, however, proceeds rapidly after arousal from hibernation in early April (Kimura \& Uchida, 1984), and the young are born in late June or early July (Uchida, 1957).

Uchida et al. (1984) showed that elevated temperatures $\left(23-25^{\circ} \mathrm{C}\right)$ and abundant food supply during winter accelerated the rate of embryonic development and that the corpus luteum cells in bats kept at an elevated temperature $\left(25^{\circ} \mathrm{C}\right)$ became active while those in hibernating bats were less active. However, information which might explain an hormonal regulation of such a reproductive mechanism is scarce. The present study was therefore carried out to measure the plasma progesterone concentrations during pregnancy in this bat.

\section{Materials and Methods}

Animals. Forty-nine gravid bats $\left(M, s\right.$. fuliginosus) were captured from abandoned mines $\left(33.6^{\circ} \mathrm{N}\right)$ in the Wakayama Prefecture, and 2 precopulatory bats which had a maturing follicle with a primary oocyte in only the left ovary at Ohsedō Cave $\left(32.5^{\circ} \mathrm{N}\right)$ in the Kumamoto Prefecture (see Table 1). Blood was taken in heparinized tubes from bats under ether anaesthesia by a cardiac puncture $38-40 \mathrm{~h}$ after capture in the pregnant bats captured before $(5$

*Reprint requests to Professor T. A. Uchida. 
November 1983) or after (1 April 1984 and 17 May 1984) hibernation and 4-5 h after capture in the unmated bats captured on 13 September 1985 . Plasma was separated by centrifugation and stored at $-20^{\circ} \mathrm{C}$ until assay. Specimens collected on 5 January 1984 were divided into two groups, i.e. the hibernating and aroused, as follows: the hibernating bats were maintained under artificial hibernation in a cold room $\left(5-7^{\circ} \mathrm{C}\right.$, humidity $\left.60 \%\right)$ for 14 days to eliminate possible arousal caused by capture; the aroused bats were kept without hibernation in a constant temperature and humidity room $\left(25 \pm 1{ }^{\circ} \mathrm{C}, 90 \%\right)$ and fed on sufficient meal worms and water for the same period. Afterwards, the bats of both groups were anaesthetized with ether and exsanguinated from the heart, and the separated plasma was stored at $-20^{\circ} \mathrm{C}$ until assay.

Radioimmunoassay. Plasma progesterone concentrations were measured by radioimmunoassay using progesterone antiserum, standard progesterone and $\left[1,2-{ }^{3} \mathrm{H}\right]$ progesterone purchased from Sorin Biomedica (Saluggia, Italy). According to the information provided with the antiserum, it had been prepared in a rabbit against $11 \alpha$-hydroxyprogesterone hemisuccinate-BSA and the following materials were checked for cross-reactivity: progesterone, $100 \%$; cortexone, $0.65 \%$; testosterone, $0.5 \% ; 17 \alpha$-hydroxyprogesterone, $0.37 \% ; 20 \alpha$-dihydroprogesterone, $0.2 \%$; pregnenolone, $0.05 \%$; androstenedione, $0.04 \%$; oestradiol, $0.01 \% ; 3 \beta, 17 \alpha$-dihydroxyprogesterone, $0.01 \%$ and androsterone, cortisol and epitestosterone, all $<0.01 \%$. The antiserum and labelled progesterone were used according to the supplier's specifications. The minute volume of plasma obtained from each bat did not allow division into duplicates, and therefore a $100 \mu \mathrm{l}$ sample for each bat was twice extracted with $2 \mathrm{ml}$ diethyl ether by vortexing for $2 \mathrm{~min}$. Procedural losses were determined by monitoring the recovery of labelled progesterone added to plasma samples from 18 specimens of 49 bats before extraction, and the average recovery ratio was $95.7 \%$. Bound and free hormones were separated by dextran-coated charcoal. The inter- and intra-assay coefficients of variation were $13 \cdot 1 \%$ and $12 \cdot 4 \%$, respectively, and the assay sensitivity was $10 \mathrm{pg} /$ tube. Ewe plasma collected in the anoestrous season was used to verify the measurement of progesterone in the assay; values obtained $(0.85 \pm 0.32 \mathrm{ng} / \mathrm{ml}$ (s.e.m.), $n=3)$ were comparable to those reported by Saba et al. (1975).

Histology. Reproductive organs from all bats were fixed in Bouin's fluid, serially sectioned at $7 \mu \mathrm{m}$, stained with haematoxylin and eosin, and the developmental stage of the embryo was determined. From the ovarian sections the volumes of the corpora lutea were estimated as described by Rowlands \& Heap (1966).

\section{Results}

\section{Progesterone concentration}

The September samples represent non-pregnant animals and the mean plasma progesterone value was $7.0 \mathrm{ng} / \mathrm{ml}$. At the delayed implantation stage in November (just before hibernation), plasma progesterone values were greater than in September but were not significantly elevated. However, in January, during delayed development, progesterone concentrations were significantly lower $(P<0.05)$ in the hibernating bats with an implanting blastocyst than in non-pregnant bats in September (Table 1). After arousal from hibernation, the progesterone concentrations increased in

Table 1. Plasma progesterone concentrations and corpus luteum volumes in Japanese long-fingered bats

\begin{tabular}{|c|c|c|c|c|c|c|}
\hline $\begin{array}{l}\text { Date } \\
\text { captured }\end{array}$ & $\begin{array}{c}\text { Date of } \\
\text { plasma } \\
\text { sampling }\end{array}$ & $\begin{array}{l}\text { Stage or size } \\
\text { of embryo }\end{array}$ & \multicolumn{2}{|c|}{$\begin{array}{l}\text { Progesterone } \\
\text { conc. }(\mathrm{ng} / \mathrm{ml})\end{array}$} & \multicolumn{2}{|l|}{$\begin{array}{l}\text { Corpus luteum } \\
\text { volume }\left(\mathrm{mm}^{3}\right)\end{array}$} \\
\hline \multicolumn{7}{|l|}{ Non-pregnancy } \\
\hline 13 September 1985 & 13 Sept. & No embryo & $7 \cdot 0 \pm 0 \cdot 1^{a}$ & (2) & No corpus luteum & \\
\hline \multicolumn{7}{|l|}{ Pregnancy } \\
\hline $\begin{array}{l}5 \text { November } 1983 \\
5 \text { January } 1984\end{array}$ & 7 Nov. & Free blastocyst & $11 \cdot 1 \pm 1 \cdot 8^{\mathrm{ac}}$ & (5) & $0.139 \pm 0.011^{\mathrm{ac}}$ & (5) \\
\hline Hibernating* & 21 Jan. & Implanting blastocyst & $4.7 \pm 0.6^{b}$ & (6) & $0 \cdot 123 \pm 0 \cdot 015^{a}$ & (4) \\
\hline Aroused $\dagger$ & 21 Jan. & Implanting blastocyst & $10 \cdot 5 \pm 1 \cdot 1^{\mathrm{cd}}$ & (6) & $0.190 \pm 0.008^{b}$ & (4) \\
\hline 1 April 1984 & 3 Apr. & Early placentation & $8.0 \pm 0.9^{\text {ad }}$ & (5) & $0.175 \pm 0.011^{b c}$ & (5) \\
\hline 17 May 1984 & 19 May & $12 \mathrm{~mm}$ conceptus & $11 \cdot 8 \pm 1 \cdot 5^{c}$ & $(10)$ & $0.180 \pm 0.009^{b}$ & (9) \\
\hline
\end{tabular}

Values are mean \pm s.e.m. for the no. of bats indicated in parentheses. Means with at least one superscript in common are not significantly different $(P>0.05$, Student's $t$ test or Cochran-Cox test).

*Maintained under artificial hibernation in a cold room $\left(5-7^{\circ} \mathrm{C}\right)$ from 7 January.

$\dagger$ Kept at an elevated temperature $\left(\sim 25^{\circ} \mathrm{C}\right)$ from 7 January. 
bats at the early placentation stage (April) to an extent comparable to that in the September samples, and were significantly $(P<0.05)$ greater in bats with a $12-\mathrm{mm}$ embryo (May). The progesterone values in the aroused bats of the January samples with an implanting blastocyst were significantly $(P<0.0 \mathrm{I})$ higher than those in the hibernating bats of the January samples.

\section{Corpus luteum volume}

The changes in the corpus luteum volume corresponded closely with those in plasma progesterone concentration during pregnancy: the volume increased after awakening from hibernation (Table 1). In the aroused bats prevented from hibernating in January, the volume was significantly $(P<0.01)$ larger than that in the hibernating bats in the same month.

\section{Discussion}

In non-hibernating bat such as the Mexican free-tailed bat, Tadarida brasiliensis mexicana (Jerrett, 1979), which exhibited no delayed implantation and development, plasma progesterone concentrations increase steadily until the mid-point of pregnancy and then decline after parturition. On the other hand, in hibernating bats such as the pallid bat, Antrozous pallidus (Oxberry, 1979), and pipistrelle bat, Pipistrellus pipistrellus (Racey \& Swift, 1981), the progesterone concentrations fluctuate until the time of a peak of progesterone just before parturition; nevertheless the progesterone concentrations during pregnancy in the 2 species do not fall to the values at the beginning of gestation and/or the baseline value. In the Japanese long-fingered bat, progesterone values were not significantly elevated during delayed implantation but were significantly depressed during retarded embryonic development after implantation (delayed development), and rose significantly after arousal from hibernation.

In the majority of species which show seasonal or obligatory delay of implantation, e.g. armadillo (Labhsetwar \& Enders, 1968; Peppler \& Stone, 1976), stoat (Gulamhusein \& Thawley, 1974), European badger (Bonnin et al., 1978), spotted skunk (Mead, 1981), northern fur seal (Daniel, 1981) and black bear (Foresman \& Daniel, 1983), the corpora lutea are less active during embryonic diapause, and the plasma progesterone concentrations stay slightly above the values in non-pregnant animals until shortly before implantation, when the concentrations begin to increase with activation of the corpora lutea. However, the roe deer, Capreolus capreolus, is unique in having an active corpus luteum throughout the diapause period, although no significant change is detected in the progesterone concentration until after implantation (Hoffman et al., 1978; Aitken, 1981). A high progesterone concentration and the presence of active corpora lutea are important for maintenance of lactational delayed implantaton in the mouse and rat (Yoshinaga, 1974; GidleyBaird, 1981). The high progesterone value during delayed implantation in Japanese long-fingered bats is therefore of interest. According to histological studies (Peyre \& Herlant, 1963a, b, 1967) on the long-fingered bat inhabiting the south of France, it is said that the corpus luteum is poorly developed throughout delayed implantation for 5 months of the entire hibernation period and that an arrest in LH secretion after ovulation, together with insufficient prolactin, is responsible for delayed implantation.

In the Japanese long-fingered bat, the plasma progesterone concentration was low and the corpus luteum volume was small at the delayed development stage. These results support our belief that the corpus luteum is less active during delayed development in this bat (Kimura \& Uchida, 1983; Uchida et al., 1984). The so-called delayed development was first described in the California leaf-nosed bat, Macrotus californicus (Bradshaw, 1962), and occurs also in the Mexican fruit bat, Artibeus jamaicensis (Fleming, 1971). In the California leaf-nosed bat, the progesterone values are low throughout delayed development and a biphasic pattern of plasma progesterone is observed during pregnancy (Burns \& Easley, 1977). Elevated ambient temperatures and ample food supplies 
failed to shorten the period of delayed development in California leaf-nosed bats (Burns, 1981); however, such a condition not only hastened embryonic development (Uchida et al., 1984) but also resulted in significant increase in both the plasma progesterone concentration and the corpus luteum volume (this study) in Japanese long-fingered bats. Therefore, the retarded embryonic development of the long-fingered bat is a direct and passive response to the cold and depressed metabolism as indicated by Kimura \& Uchida (1983), and seems to differ essentially from that of the above 2 non-hibernating species. On the other hand, in the pipistrelle bat, delayed development can take place experimentally under cold conditions after fetuses have reached a palpable size (Racey, 1973); under natural conditions also, the gestation period is extended in cold weather, and the duration of the low progesterone period that occurs between the apparent initial rise and fall in early pregnancy and the later high levels just before parturition is lengthened (Racey \& Swift, 1981), and this prolonged period of low progesterone seems to coincide with the period of cold weather. This phenomenon in the pipistrelle bat may be analogous to the low progesterone period that appears to occur in response to the cold during delayed development in the Japanese long-fingered bat.

The baseline level $(7 \mathrm{ng} / \mathrm{ml})$ of plasma progesterone in the Japanese long-fingered bat during a period when no luteal tissue was present was similar to that $(\sim 5 \mathrm{ng} / \mathrm{ml})$ reported for the pallid bat (Oxberry, 1979) and the Mexican free-tailed bat (Jerrett, 1979), but the baseline values in the California leaf-nosed bat appear as 'zero' (Burns \& Easley, 1977). Relatively high baseline values of plasma progesterone observed during non-pregnancy in the former 3 bat species suggest that the measured progesterone is secreted by the ovarian interstitial gland tisue as suggested for the Mexican free-tailed bat (Jerrett, 1979) and/or by the adrenal cortex as in the ewe (McCracken \& Baird, 1969) and women (Baird, 1976). On the other hand, ACTH stimulation can increase plasma progesterone values $350-500 \%$ over baseline levels in post-menopausal women (Vermeulen, 1976). It is still possible, therefore, that stress of bats by artificial incidents such as capture and transport may influence the plasma progesterone concentrations. Although the adrenal glands of many hibernators undergo seasonal changes in size and activity (Wang, 1982), such changes have not been studied in Japanese long-fingered bats. The endocrine control mechanisms of delayed implantation and development in Japanese long-fingered bats require further study.

We thank Professor E. W. Jameson, Jr, Department of Zoology, University of California, for comments on the manuscript, and Mr S. Minato for his help in collecting animals. This work was supported in part by Grant-in-Aid for Scientific Research (No. 61740416) from the Ministry of Education, Science and Culture, Japan.

\section{References}

Aitken, R.J. (1981) Aspects of delayed implantation in the roe deer (Capreolus capreolus). J. Reprod. Fert., Suppl. 29, 83-95.

Baird, D.T. (1976) Ovarian steroid secretion and metabolism in women. In The Endocrine Function of the Human Ovary, pp. 125-133. Eds V. H. T. James, M. Serio \& G. Giusti. Academic Press, London.

Bonnin, M., Canivenc, R. \& Ribes, Cl. (1978) Plasma progesterone levels during delayed implantation in the European badger (Meles meles). J. Reprod. Fert. 52, 55-58.

Bradshaw, G.V.R. (1962) Reproductive cycle of the California leaf-nosed bat, Macrotus californicus. Science, N.Y. 136, 645-646.

Burns, J.M. (1981) Aspects of endocrine control of delay phenomena in bats with special emphasis on delayed development. J. Reprod. Fert., Suppl. 29, 61-66.

Burns, J.M. \& Easley, R.G. (1977) Hormonal control of delayed development in the California leaf-nosed bat, Macrotus californicus. III. Changes in plasma progesterone during pregnancy. Gen. comp. Endocrinol. 32, $163-166$.

Daniel, J.C., Jr (1981) Delayed implantation in the northern fur seal (Callorhinus ursinus) and other pinnipeds. J. Reprod. Fert., Suppl. 29, 35-50.

Fleming, H. (1971) Artibeus jamaicensis: delayed embryonic development in a neotropical bat. Science, N.Y. 171, 402-404.

Foresman, K.R. \& Daniel, J.C., Jr (1983) Plasma progesterone concentrations in pregnant and nonpregnant black bears (Ursus americanus). J. Reprod. Fert. 68, 235-239.

Gidley-Baird, A.A. (1981) Endocrine control of implantation and delayed implantation in rats and mice. $J$. Reprod. Fert., Suppl. 29, 97-109.

Gulamhusein, A.P. \& Thawley, A.R. (1974) Plasma pro- 
gesterone levels in the stoat. $J$. Reprod. Fert. 36, 405-408.

Hoffman, B., Barth, D. \& Karg, H. (1978) Progesterone and estrogen levels in peripheral plasma of the pregnant and nonpregnant roe deer (Capreolus capreolus). Biol. Reprod. 19,931-935.

Jerrett, D.P. (1979) Female reproductive patterns in nonhibernating bats. $J$. Reprod. Fert. 56, 369-378.

Kimura, K. \& Uchida, T.A. (1983) Ultrastructural observations of delayed implantation in the Japanese long-fingered bat, Miniopterus schreibersii fuliginosus. J. Reprod. Fert. 69, 187-193.

Kimura, K. \& Uchida, T.A. (1984) Development of the main and accessory placentae in the Japanese longfingered bat, Miniopterus schreibersii fuliginosus. $J$. Reprod. Fert. 71, 119-126.

Labhsetwar, A.P. \& Enders, A.C. (1968) Progesterone in the corpus luteum and placenta of the armadillo, Dasypus novemcinctus. J. Reprod. Fert. 16, 381-387.

McCracken, J.A. \& Baird, D.T. (1969) The study of ovarian function by means of transplantation of the ovary in the ewe. In The Gonads, pp. 175-209. Ed. K. W. McKerns. North-Holland Publishing Company, Amsterdam.

Mead, R.A. (1981) Delayed implantation in mustelids with special emphasis on the spotted skunk. $J$. Reprod. Fert., Suppl. 29, 11-24.

Mōi, T. \& Uchida, T.A. (1980) Sperm storage in the reproductive tract of the female Japanese long-fingered bat, Miniopterus schreibersii fuliginosus. J. Reprod. Fert. 58, 429-433.

Mōri, T. \& Uchida, T.A. (1981a) Ultrastructural observations of fertilization in the Japanese long-fingered bat, Miniopterus schreibersii fuliginosus. J. Reprod. Fert. 63, 231-235.

Mōri, T. \& Uchida, T.A. (1981b) Ultrastructural observations of ovulation in the Japanese long-fingered bat, Miniopterus schreibersii fuliginosus. J. Reprod. Fert. 63, 391-395.

Mōi, T. \& Uchida, T.A. (1982) Changes in the morphology and behaviour of spermatozoa between copulation and fertilization in the Japanese longfingered bat, Miniopterus schreibersii fuliginosus. $J$. Reprod. Fert. 65, 23-28.

Oxberry, B.A. (1979) Female reproductive patterns in hibernating bats. J. Reprod. Fert. 56, 359-367.

Peppler, R.D. \& Stone, S.C. (1976) Plasma progesterone level in the female armadillo during delayed implantation and gestation: preliminary report. Lab. Anim. Sci. 26, 501-504.

Peyre, A. \& Herlant, M. (1963a) Ovo-implantation différee et corrélations hypophyso-génitales chez la femelle du Minioptère (Miniopterus schreibersii B.). C. r. hebd. Séanc. Acad. Sci., Paris D 257, 524-526.

Peyre, A. \& Herlant, M. (1963b) Correlations hypophyso-génitales chez la femelle du Minioptère (Miniopterus schreibersii B.). Gen. comp. Endocr. 3, 726-727.
Peyre, A. \& Herlant, M. (1967) Ovo-implantation différée et déterminisme hormonal chez le Minioptère, Miniopterus schreibersii K. (Chiroptère). C. r. Séanc. Soc. Biol. 161, 1779-1782.

Racey, P.A. (1973) Environmental factors affecting the length of gestation in heterothermic bats. $J$. Reprod. Fert., Suppl. 19, 175-189.

Racey, P.A. \& Swift, S.M. (1981) Variations in gestation length in a colony of pipistrelle bats (Pipistrellus pipistrellus) from year to year. J. Reprod. Fert. 61, 123-129.

Richardson, E.G. (1977) The biology and evolution of the reproductive cycle of Miniopterus schreibersii and $M$. australis (Chiroptera: Vespertilionidae). J. Zool., Lond. 183, 353-375.

Rowlands, I.W. \& Heap, R.B. (1966) Histological observations on the ovary and progesterone levels in the coypu, Myocastor coypus. Symp. zool. Soc. Lond. 15, 335-352.

Saba, N., Cunningham, N.F., Symons, A.M. \& Millar, P.G. (1975) The effect of progesterone implants on ovulation and plasma levels of $\mathrm{LH}, \mathrm{FSH}$ and progesterone in anoestrous ewes. J. Reprod. Fert. 44, 59-68.

Uchida, T.A. (1957) Fertilization and hibernation in bats. Heredity, Tokyo 11, 14-17. [In Japanese.]

Uchida, T.A., Inoue, C. \& Kimura, K. (1984) Effects of elevated temperatures on the embryonic development and corpus luteum activity in the Japanese longfingered bat, Miniopterus schreibersii fuliginosus. $J$. Reprod. Fert. 71, 439-444.

van der Merwe, M. (1980) Delayed implantation in the Natal clinging bat Miniopterus schreibersii natalensis (A. Smith, 1834). In Proc. 5th Int. Bat Res. Conf., pp. 113-123. Eds D. E. Wilson \& A. L. Gardner. Texas Tech. Press, Lubbock.

Vermeulen, A. (1976) Postmenopausal ovarian function. In The Endocrine Function of the Human Ovary, pp. 237-244. Eds V. H. T. James, M. Serio \& G. Giusti. Academic Press, London.

Wang, L.C.H. (1982) Hibernation and the endocrines. In Hibernation and Torpor in Mammals and Birds, pp. 206-236. Eds C. P. Lyman, J. S. Wills, A. Malan \& L. C. H. Wang. Academic Press, London.

Wimsatt, W.A. (1969) Some interrelationships of reproduction and hibernation in mammals. Symp. Soc. exp. Biol. 23, 511-549.

Yoshinaga, K. (1974) Ovarian progestin secretion in lactating rats: effect of intrabursal injection of prolactin antiserum, prolactin and LH. Endocrinology 94, 829-834. 